4. Armstrong MJ, Shulman LM, Vandigo J, Mullins CD. Patient engagement and shared decision-making: what do they look like in neurology practice? Neurol Clin Pract 2016;6:190-197.

5. Heesen C, Kasper J, Segal J, Kopke S, Muhlhauser I. Decisional role preferences, risk knowledge and information interests in patients with multiple sclerosis. Mult Scler 2004;10:643-650.

6. Kasper J, Kopke S, Muhlhauser I, Nubling M, Heesen C. Informed shared decision making about immunotherapy for patients with multiple sclerosis (ISDIMS): a randomized controlled trial. Eur J Neurol 2008;15:1345-1352.

7. Poulos C, Kinter E, Yang JC, et al. A discrete-choice experiment to determine patient preferences for injectable multiple sclerosis treatments in Germany. Ther Adv Neurol Disord 2016;9:95-104.

8. Utz KS, Hoog J, Wentrup A, et al. Patient preferences for disease-modifying drugs in multiple sclerosis therapy: a choice-based conjoint analysis. Ther Adv Neurol Disord 2014;7:263-275.

9. Wilson LS, Loucks A, Gipson G, et al. Patient preferences for attributes of multiple sclerosis disease-modifying therapies: development and results of a ratings-based conjoint analysis. Int J MS Care 2015;17:74-82.

10. Ng P, Murray S, Hayes SM. Clinical decision-making in multiple sclerosis: challenges reported internationally with emerging treatment complexity. Mult Scler Relat Disord 2015;4:320-328.

11. Saposnik G, Sempere AP, Prefasi D, et al. Decision-making in multiple sclerosis: the role of aversion to ambiguity for therapeutic inertia among neurologists (DIScUTIR MS). Front Neurol 2017;8:65

12. Rae-Grant A, Day GS, Marrie RA, et al. Practice guideline recommendation summary: disease-modifying therapies for adults with multiple sclerosis: Report of the Guideline Development, Dissemination, and Implementation Subcommittee of the American Academy of Neurology. Neurology 2018;90: $777-788$

13. Marrie RA, Cutter G, Tyry T, Campagnolo D, Vollmer T. Validation of the NAR COMS registry: diagnosis. Mult Scler 2007;13:770-775.

14. Marrie RA, Goldman M. Validity of performance scales for disability assessment in multiple sclerosis. Mult Scler 2007;13:1176-1182

15. Schwartz CE, Vollmer T, Lee H. Reliability and validity of two self-report measures of impairment and disability for MS. North American Research Consortium on Multiple Sclerosis Outcomes Study Group. Neurology 1999;52:63-70.
16. Gronseth GS, Woodroffe LM, Getchius TSD. Clinical Practice Guideline Process Manual. St. Paul, MN: American Academy of Neurology; 2011.

17. Rosato R, Testa S, Oggero A, Molinengo G, Bertolotto A. Quality of life and patient preferences: identification of subgroups of multiple sclerosis patients. Qual Life Res $2015 ; 24: 2173-2182$

18. US Food and Drug Administration. Guidance for industry: providing clinical evidence of effectiveness for human drugs and biological products. Available at: fda.gov/ downloads/Drugs/GuidanceComplianceRegulatoryInformation/Guidances/UCM072008. pdf. Accessed May 19, 2017.

19. Office of the Auditor General of Canada. Regulating Pharmaceutical Drugs: Health Canada. Report of the Auditor General of Canada to the House of Commons [serial online]. 2011. Available at: publications.gc.ca/collections/collection_2012/bvg-oag/ FA1-2011-2-4-eng.pdf. Accessed May 19, 2017.

20. European Commission. Health and Food Safety Directorate-general. Procedures for Marketing Authorisation: Marketing Authorization. Brussels: European Commission; 2016: $1-49$.

21. Panitch H, Miller A, Paty D, Weinshenker B, North American Study Group on Interferon beta- $1 \mathrm{~b}$ in Secondary Progressive MS. Interferon beta- $1 \mathrm{~b}$ in secondary progressive MS results from a 3-year controlled study. Neurology 2004;63:1788-1795.

22. Cohen JA, Cutter GR, Fischer JS, et al. Benefit of interferon beta-1a on MSFC progression in secondary progressive MS. Neurology 2002;59:679-687.

23. Gold R, Giovannoni G, Selmaj K, et al. Daclizumab high-yield process in relapsingremitting multiple sclerosis (SELECT): a randomised, double-blind, placebocontrolled trial. Lancet 2013;381:2167-2175.

24. Shay LA, Lafata JE. Where is the evidence? A systematic review of shared decision making and patient outcomes. Med Decis Making 2015;35:114-131.

25. Colligan E, Metzler A, Tiryaki E. Shared decision-making in multiple sclerosis. Mult Scler 2017;23:185-190.

26. Stacey D, Legare F, Col NF, et al. Decision aids for people facing health treatment or screening decisions. Cochrane Database Syst Rev 2014:CD001431.

27. Elwyn G, Frosch DL, Kobrin S. Implementing shared decision-making: consider all the consequences. Implement Sci 2016;11:114.

28. The Guidelines International Network Public and Patient Involvement Working Group. G-I-N Public Toolkit: Patient and Public Involvement in Guidelines. 2015. Available at g-i-n.net/document-store/working-groups-documents/g-i-n-public/ toolkit/toolkit-2015. Accessed May 19, 2017.

\title{
Apathy and functional disability in behavioral variant frontotemporal dementia
}

\author{
Neurology: Clinical Practice June 2018 vol. 8 no. 3185 doi:10.1212/CPJ.0000000000000475
}

In the article "Apathy and functional disability in behavioral variant frontotemporal dementia" by M.S. Yassuda et al., there is an error in the seventh author's name, which should have read "Viviane Amaral-Carvalho" rather than "Viviane AlmaralCarvalho" as originally published. The authors regret the error.

\section{Reference}

1. Yassuda MS, Lima da Silva TB, O’Connor CM, et al. Apathy and functional disability in behavioral variant frontotemporal dementia. Neurol Clin Pract 2018;8:120-128. 


\title{
Neurology ${ }^{\circ}$ Clinical Practice
}

\author{
Apathy and functional disability in behavioral variant frontotemporal dementia \\ Neurol Clin Pract 2018;8;185 \\ DOI 10.1212/CPJ.0000000000000475
}

This information is current as of June 11, 2018

Updated Information \&
Services
References
Permissions \& Licensing
Reprints

including high resolution figures, can be found at:

http://cp.neurology.org/content/8/3/185.full.html

This article cites 1 articles, 1 of which you can access for free at: http://cp.neurology.org/content/8/3/185.full.html\#\#ref-list-1

Information about reproducing this article in parts (figures,tables) or in its entirety can be found online at:

http://cp.neurology.org/misc/about.xhtml\#permissions

Information about ordering reprints can be found online:

http://cp.neurology.org/misc/addir.xhtml\#reprintsus

Neurol Clin Pract is an official journal of the American Academy of Neurology. Published continuously since 2011, it is now a bimonthly with 6 issues per year. Copyright ( 92018 American Academy of Neurology. All rights reserved. Print ISSN: 2163-0402. Online ISSN: 2163-0933.

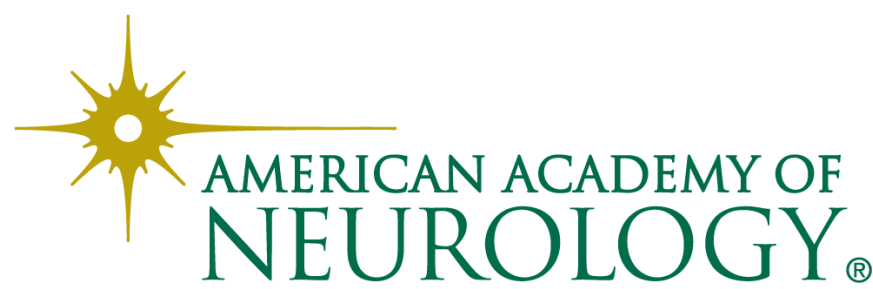

